\title{
Investigation of the Metaphorical
Perceptions of the Parents on the \\ Investigation of the Metaphorical
Perceptions of the Parents on the Concept of "Mathematics"
}

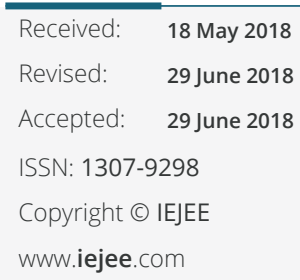

DOI: 10.26822/iejee.2018541311

\author{
Veli Toptaşa, ${ }^{a,}$, Emine Gözel ${ }^{b}$
}

\begin{abstract}
The main purpose of this research is to reveal the parents' perceptions of the concept of "mathematics" through metaphors. This research, which is followed by the qualitative research paradigm, is designed with a phenomenology design. This study is consists of 64 parents whose children are primary school students in a public school in the Central Anatolia region during the spring semester of the 2017-2018 academic year. All the parents who participated in the study were included in the study group on a voluntary basis. The data were gathered with the "Mathematics ......."; because ........ "sentence directed to the parents. The data were analyzed by content analysis technique. According to the aim of the study, the perceptions of parents' emotions and thoughts evoking the mental concept of their parents were examined. As a result of the research, the metaphors are collected under 13 conceptual categories: "life, game, air-water, road-bridge-key, novel writing, functioning iron, tree, chainring, a remaining song and bee ". Especially "life", "play" and "air-water" metaphors came to the forefront among the perceptions of the "mathematics" concept of the parents
\end{abstract}

Keywords: Parent, concept of mathematics, metaphor, perception

\section{Introduction}

One of the most important problems in the world and in our country is education. Parent-teacher association is fundamental to prevent the failure and the problems related to the education system and raise qualified individuals, in crease the motivation of students (Dam, 2008). As regards education, the first course that comes to mind is mathematics. Mathematics, a science as old as human history, is an interdisciplinary field that is effective in the development of science and technology. In fact, mathematics is considered in parallel with the success, development, and training of a country (Işık, Çiltaş \& Bekdemir, 2008) because the best way to cope with environmental events and improve quality of life is to produce mathematical models and to think mathematically.

The mathematical thinking of the students who are the target audience of the education- training process (Nasibov \& Kaçar, 2005) is important in terms of having and developing a positive attitude towards mathematics.

The ability to solve logical problems based on knowledge of why and how and to know and use mathematical techniques is mathematical power (Ryan, 1998). On the other hand, it is possible to say that mathematics is nested in daily life and mathematics is used to solve problems that are both routine and non-routine. Therefore, mathematics is very effective in raising the quality of education and achieving specific goals (Carter \& Norwood, 1997; Frank, 1990; Underhill, 1988). In this context, mathematics is described as "... ability to think, the fundamental ability of human that distinguish him from other living beings and make inferences from the events and rearrange conditions in his own way" (Umay, 2003). However, since mathematics is an abstract course as it involves reasoning, building relationship, problem-solving and takes too much time in a solution process, it becomes relatively more difficult than other courses (Başar, Ünal \& Yalçın, 2002; Tarim, Bulut Özsezer \& Canbazoğlu, 2017; Umay, 2003). Does this stem from the fact that Mathematics is a difficult lesson or are the students afraid of not solving mathematical problems? That is why mathematics is a fearful dream for students (Işık, Çiltaş \& Bekdemir, 2008). At this point, what teachers instruct and how they evaluate comes to the forefront. How much knowledge the teachers and pre-service teachers have in terms of pedagogy and the role of educators in the learning-teaching process have been disputed for years by experts. Because the mathematical knowledge and concepts taught during the primary school period will ensure children to grow up as individuals who can use mathematics in the future.

On the other hand, one of the factors affecting school success is the family (Burns, Roe \& Ross, 1992, Chu \& Williams, 1996, Griffith, 1996). As a matter of fact, a child gains his first mathematical experience in the family. Before the education begins, children learn mathematical concepts informally (Akman, 2002). If the objective is to raise the interest of students towards mathematics and increase the level of academic achievement, teachers should establish the link between school and the family and have the parents participate to the education process (Funkhouser \& Gonzales, 1997). It is an undeniable fact that the parents are as important as teachers for the success of the students in the mathematics. In this context, parents of the students are indispensable for the education. Hence, mathematics is also important for the parents as it is for the students and the teachers. For this reason, it should be known what the parents think about mathematics and what their feelings and thoughts are associated with their minds regarding the concept of mathematics, because students are greatly affected by the concerns and attitudes of the parents. In particular, it is crucial that the parents of the first graders of an elementary school have a sense of mathematics and a view of mathematics. In this respect, it is important that the parents are able to give open and satisfactory answers to the problems of the students in mathematics. This is because the development of mathematical thinking skills of the parents and the application of 
these skills in their lives will also contribute positively to the students.

As science and technology develop, new concepts enter our daily lives. In this context, metaphors are thought to be a powerful modeling tool for interpreting and explicating individual perceptions and thoughts of a person from a different point of view (Balcl, 1999, Palmquist, 2001, Yob, 2003). Indeed, metaphors also aim to increase the critical thinking skills of an individual and to stimulate creative thinking (Bahadır \& Özdemir, 2012). Therefore metaphors can be described as a thing that is explained with a known thing by comparing it to concrete concepts and phenomenon (Lakoff \& Johnson, 1980; Perry \& Cooper, 2001; Şahin, 2013; Tarim, Bulut Özsezer \& Canbazoğlu, 2017; Taylor, 1984). Metaphors make it easier to learn by putting forth the mental schema of a new knowledge, as well as establishing relationships among the concepts. In this way, the past experiences of the individuals come to the forefront (Nesliturk, Çamlıbel Çakmak \& Asar, 2014; Oflaz, 2011; Saban, 2004; Semerci, 2007). Metaphors, therefore, can be described as establishing a similarity or association between known knowledge and another previously known knowledge. Metaphors in education try to embody an abstract thing using the symbolic language structure. Thanks to the metaphors, concepts are also associated with everyday life, apart from their true meaning.

It is thought that "A metaphor, which is mostly used in literature, is a figure of speech commonly used for embellishing the language we use in everyday life"(Saban, 2004). However, researchers view metaphors as a powerful too in explaining concepts and phenomena in education. Recently, studies in social sciences through metaphors have increased considerably. (Balcl, 1999; Neslitürk, Çamlıbel Çakmak \& Asar, 2014; Semerci, 2007).In national and international education literature, studies examining the metaphor perceptions for the concepts such as "mathematics", "mathematics education" and "mathematics problem" of students, teachers, pre-service teachers and instructors have been found (Bahadır \& Özdemir, 2012; Ersoy \& Aydın, 2017; Gür, Hangül \& Kara, 2014; Noyes, 2006; Oflaz, 2011; Sterenberg, 2008; Şahin, 2013). First of all, based on the studies carried out with the students, Akbaşlı et al., (2017), trying to reveal the perceptions of middle school students through metaphors related to the concepts of "mathematics teacher" and "mathematics lesson" (2017) found that elementary school students thought Mathematics is in the category of a difficult and boring subject. In the study of Bahadır and Özdemir (2012), it was understood that 7-th grade students produced metaphors such as a calculator, sleep, horror movie regarding the concept of mathematics. Likewise, Ersoy and Aydin (2017) formed the category of "friends, entertainment, lifestyle" as the most used ones and another category of "process, problem, solution, lesson" as the least used ones according to the metaphors of the 4 th graders regarding the concept of mathematics they had. Again, Gür, Hangül and Kara (2014) conceptualized mathematics through the metaphors of elementary and high school students in categories such as "difficulty / simplicity / nature of mathematics, necessity of mathematics, student interest / attitude, teacher's interest / attitude". In another study, Oflaz (2011) found that elementary school students conceptualize mathematics in categories such as "friends and lost people, apartments, cars, unstitched socks, baklava, mandarin, tree, flower, life.

When the studies conducted with teachers and pre-service teachers are examined; it was seen that pre-service teachers identified mathematics with development, production and travel (Reeder, Utley \& Cassel 2009), and the study of
Güler, Akgün, Öçal \& Doruk (2012) aimed to reveal metaphorical thinking of the pre-service elementary school Math teachers found that they identified mathematics concept with "life, puzzle and water". In another metaphor study conducted with pre-service mathematics teachers, it was determined that they formed categories such as "language for teaching mathematics, travel to unknown, tool box (Noyes, 2006). Güner (2013) found that pre-service classroom teachers thought that mathematical concept is an "enjoyable pursuit", while pre-service social sciences teachers thought that mathematics make their life difficult ".However, it is stated that the majority of the pre-service teachers have the opinion that "mathematics is the life itself". In the study of Güveli et al. (2011), it was seen that pre-service classroom teachers formed metaphors for the concept of mathematics, such as "mathematics as an exciting course ", "mathematics as a difficult and boring course "and "mathematics composed of many subjects". Sahin (2013) revealed in his study on the perceptions of pre-service teachers for "Mathematics teacher", "Mathematics" and "Mathematics lesson" that they identified the concept of Mathematics with "Intelligence", Enjoyable", "Necessary", "Ability" and "Achievement" at the most and with the "Unnecessary", "Easy" and "Authority" metaphors at the least. In a similar study, Tarım, Bulut Özsezer and Canbazoğlu (2017) understood that pre-service classroom teachers constitute categories such as "life, brain box, game, puzzle, computer" for the concept of "mathematics". It was also understood that instructors who teach mathematics regard "mathematics teaching" as an effort, a craft (Allen \& Shiu, 1997). In another metaphor study, it was concluded that classroom teachers viewed "mathematics" as a mountain with a hard-to-reach summit, struggling, a different language and a bridge (Sterenberg, 2008). However, in the literature, there are no studies attempting to reveal the metaphor perceptions of the parents about the concept of mathematics. In fact, it is important to reveal the perceptions of the parents for the concept of mathematics through the metaphors in terms of the authenticity of the study. Knowing what the metaphorical perceptions of the parents versus mathematics are will be a great convenience for the teacher. Because it is thought that this study will be effective in revealing the mathematical thinking of the parents about mathematics. At the same time, how the concept of mathematics reflects on the parents will be revealed as well. As a result, the teacher will better understand the level of readiness of the students for mathematics teaching and will arrange the learning process accordingly and direct the practices effectively. In this context, the purpose of this study is to reveal the perceptions of the parents about the concept of "mathematics" through metaphors. Within this framework, the answer to the following question was sought:

1) What can conceptual categories be constituted for the common features of the metaphoric perceptions of the parents' "mathematics" concept?

\section{Method}

In this study, phenomenology pattern, one of the qualitative research methods is used. Phenomenology focuses on what we are aware of, but we do not have an in-depth and detailed understanding. It is generally aimed to reveal and interpret individual perceptions of a phenomenon in the case studies (Yıldırım \& Şimşek, 2008). In line with this aim, the thoughts and feelings of the parents' for the concept of mathematics were tried to be analyzed.

\section{Study group}

This study group consists of 64 parents of the students at 
one primary school in the Central Anatolian Region during the spring semester of the 2017-2018 academic years. All parents participated in the study were included in the study group on a voluntary basis.

\section{Data Collection}

After the applications of some selected concepts in the literature on the concept of metaphors and the information was given, the parents were asked to complete the sentence of; "Mathematics is like (is similar to) ..........; because ............." in order to reveal their perceptions about the concept of mathematics. In addition, three lecturers specialized in mathematics were interviewed regarding the selection of metaphors. The concept of "because" was chosen to allow participants in the study to provide a justification / rationale for metaphors

\section{Data Analysis}

The analysis of the data was carried out in three stages. Firstly, descriptive analysis of the sources of the metaphors used by the parents was tabulated. In the tables, the frequency of the metaphorical sources the parents wrote about each metaphor is given. In the second stage, a thorough examination of the relationship between the source of metaphors, the subject of metaphors, and the source has been carried out. At this stage, the answers that are thought to provide the contribution to the understanding of the mathematical concept, in which no logical basis for the metaphor is presented, are excluded from the analysis.

As a result, metaphors are gathered under 13 conceptual categories of "life, play, etc." in terms of their mathematical features. The metaphors expressing the perceptions of the parents about the mathematics concept were analyzed by content analysis method and frequency and percentage values were calculated by encoding the data. Then, the numbers ( $f$ ) and percentages (\%) of the students and their parents in each category of the data transferred to the computer were found. To provide reliability in the research, the metaphors were first matched with the conceptual categories by three researchers after the sorting process, At the same time, this research is similar to the data analysis process of many research (Ersoy \& Aydın, 2017; Gür, Hangul \& Kara, 2014; Güveli et al., 2011; Oflaz, 2011; Saban, 2004; Şahin, 2013)

The reliability of the research was determined by using Miles and Huberman's (1994) Reliability = consensus / (consensus + difference of opinions) formula by determining the numbers thereof. Given that the authors believe that the level of $90 \%$ and over is regarded as reliable, a $92 \%$ consensus (reliability) obtained in the study is considered satisfactory in terms of the reliability. In qualitative research, it is important to report the collected data in detail and to explain how the researcher finds the results (Yıldırım \& Şimşek, 2008). Specific explanations of how this conceptual category is found are given in detail, and findings from the views of the student and parents are presented in the findings.

Findings

Parents' Metaphoric perceptions of the concept of Mathematics

For the findings of this study which aimed to reveal the metaphorical perceptions of the parents about the concept of mathematics, the names of the metaphors produced by the parents and the frequencies and percentages of the parents producing the metaphor and the common features of the metaphors for the concept of mathematics are given in table 1

Table 1. Percentage and frequency of the metaphors generated by the parents for the concept of mathematics

\begin{tabular}{|c|c|c|c|}
\hline Name of Metaphor & $\begin{array}{l}\text { Parents representing the } \\
\text { metaphor Frequency }(\mathrm{N})\end{array}$ & $\begin{array}{l}\text { Percentage } \\
\quad(\%)\end{array}$ & Because... \\
\hline Life & 29 & 18.56 & $\begin{array}{c}\text { There are problems that need to be solved in } \\
\text { life like in mathematics. Problems will disappear } \\
\text { when solved. }\end{array}$ \\
\hline Game & 15 & 9.6 & $\begin{array}{c}\text { Mathematics is like the puzzle. There are a num- } \\
\text { ber of processes that arouse curiosity like fun } \\
\text { puzzle in every area of Mathematics. }\end{array}$ \\
\hline Air-water & 7 & 4.48 & They have to be in our lives as long as we live. \\
\hline Road-bridge-key & 3 & 1.92 & $\begin{array}{c}\text { It is a key for unlocking the difficulties we face } \\
\text { in daily life and it takes us from one place to } \\
\text { another. }\end{array}$ \\
\hline Novel writing & 1 & 0.64 & It develops and opens the human mind. \\
\hline Rolling stone & 1 & 0.64 & It takes shape as it is used. \\
\hline Tree & 1 & 0.64 & $\begin{array}{c}\text { As a tree cannot grow without love and patience, } \\
\text { mathematics cannot be learned either. }\end{array}$ \\
\hline Chainring & 1 & 0.64 & It disconnects when one item comes off. \\
\hline Ball of string & 1 & 0.64 & $\begin{array}{l}\text { It is complicated at first sight. As it is solved, it } \\
\text { becomes easy and enjoyable. }\end{array}$ \\
\hline Separation & 1 & 0.64 & $\begin{array}{l}\text { We always remove some people from our lives, } \\
\text { which is the case in Mathematics as well. }\end{array}$ \\
\hline Everest & 1 & 0.64 & It is difficult to reach. \\
\hline Incomplete song & 1 & 0.64 & Not everybody knows all of it. \\
\hline Bees & 1 & 0.64 & $\begin{array}{c}\text { When it does not visit every flower one by one, it } \\
\text { cannot get honey. }\end{array}$ \\
\hline
\end{tabular}


As seen in Table 1, parents conceptualized mathematics with 13 metaphors. Of these metaphors, 9 were categorized by the parents. Other metaphors are in decreasing order as the following; Life (29 students), game (15 students), air-water (7 students) and road-bridge-key (3 students). According to this finding, it is seen that the most repeated metaphors regarding the concept of the mathematics of the parents are life (18.56\%), game $(9.6 \%)$ and air-water $(4.48 \%)$ respectively. The parents justified their comparison it to "life" with sentences like "There are problems in life that need to be solved like in mathematics. Problems will disappear when solved. "; 'Mathematics is like a puzzle game. There are a number of processes that arouse curiosity like a fun puzzle in every area of Mathematics; and "air-water" with the sentence of" They have to be in our lives for as long as we live."

Again according to Table 1, the parents also categorized metaphors for mathematics with the concepts of nature (tree, bee). In addition, the parents have also associated mathematics with negative beings. When the common features of the negative metaphors for the concept of mathematics are examined, one parent identified mathematics with the metaphor of 'separation'; "We always remove some people from our lives. This is the case in mathematics"; 1 parent explained his "Everest "metaphor as something hard to reach; another one explained the metaphor of incomplete song as "Not everybody knows all of it"

It is understood from the findings that the metaphorical perceptions of the parents about mathematics were mostly gathered under positive judgments.

\section{Discussion, Conclusion and Recommendations}

According to the results of the study, in which the metaphoric perceptions of the parents for the concept of mathematics were examined, were collected under several important categories. The first three metaphors according to the views of the parents are life, game and air-water concepts. In the first instance, the parents conceptualized mathematics with life in their minds. The parents explained the reason for this is in this sentence; "There are problems in life that need to be solved like in mathematics. Problems disappear when solved". In related literature, the studies conducted with the students and pre-service teachers, life metaphor was the common one (Oflaz, 2011; Guler, Akgün, Öçal \& Doruk, 2012; Tarim, Bulut Özsezer \& Canbazoğlu, 2017; Ersoy \& Aydın, 2017). In a similar study, Güner (2013) found that the pre-service teachers combined mathematics with the "mathematics is the life itself" category. Studies show that there is a similarity between the metaphor of life and the one emerging in this study. Therefore, it can be said that the parents have a good point of view against mathematics.

Secondly, the parents conceptualized math as a game in their minds. The parents justified their reason in this sentence; "Mathematics is like a puzzle game. There are a number of processes that arouse curiosity like fun puzzle in every area of Mathematics". With regard to this situation, Ersoy and Aydın (2017) formed the "entertainment" category for the mathematics concept of the 4th grade primary school students. In a similar study, Tarim, Bulut Özsezer and Canbazoğlu (2017) found that pre-service class teachers constitute categories with most repeated metaphors of "game, puzzle" for the concept of mathematics. On the other hand, Güner (2013) found that pre-service class teachers combined under the category "mathematics is an enjoyable pursuit". These results seem to support the work done.
In the third place, the parents conceptualize mathematics as air-water in their minds. The parents justified the reason for this with the sentence of "They have to be in our lives for as long as we live we have to be in our lives for as long as we live." In the study of Güler, Akgün, Öçal, and Doruk (2012), aiming to reveal metaphoric perceptions of the pre-service secondary school maths teachers, it was found that the metaphor of "water" was the common one. At this point, the metaphor emerging in the current research is similar to one in the study of Güler, Akgün, Öçal and Doruk (2012). Therefore, this result seems to support the findings of this study.

Nevertheless, it was seen that students and parents also categorized mathematics with negative concepts. When the common features of the negative metaphors for the concept of mathematics are examined, one of the parents identified mathematics with the metaphor of 'separation'; 1 parent explained the metaphor of an incomplete song. The reason was explained in the sentences of "We always remove some people from our lives. This is the case in mathematics" and "Not everybody knows all of it". In his work on metaphor perceptions of elementary school students for mathematics Oflaz (2011) concluded that the metaphor for mathematics is the "lost human". This finding overlaps with the findings of the study. Likewise, parents used the metaphor of "Everest" in a sentence of "It is hard to reach", or the ring of a chain thinking that when a ring of a chain breaks, the connections will all get broken. In a similar metaphor study, it was seen that classroom teachers formed a metaphor for "mathematics" like a mountain which is difficult to reach (Sterenberg, 2008). The students and pre-service teachers explained Mathematics through metaphors with difficult concepts in their minds (Akbası et al., 2017; Güveli et al.; 2011, Şahin, 2013; Gür, Hangul \& Kara; 2014).

This study aimed to reveal the perceptions of the parents for the concept of "mathematics" through metaphors. In the future, in-depth examination can be conducted to reveal the thoughts of the parents for the concept of "mathematics "with the interview technique, which is one of the qualitative research methods. Besides this, parents' developing negative feelings towards mathematics should be avoided. At this point, pre-school and classroom teachers can conduct a workshop with family involvement with parents. This study was carried out by the parents of primary school students. Further studies can be carried out by parents at different grade levels.

\section{References}

Akbaşlı, S., Üredi, L., Yocu, H. \& Loğoğlu, P. (2017). Ortaokul öğrencilerinin matematik öğretmeni ve matematik dersine yönelik metaforik algılarının incelenmesi. Kastamonu Eğitim Dergisi, 25(6), 2283-2294.

Akman, B. (2002). Okul öncesi dönemde matematik. Hacettepe Üniversitesi Eğitim Fakültesi Dergisi, 23, 244248.

Allen, B. \& Shiu, C. (1997). Learning mathematics is like...'views of tutors and students beginning a distance taught an undergraduate course. In Proceedings of the British Society for Research into Learning Mathematics (pp. 8-11). The University of Oxford.

Altun, M. (2006). Matematik öğretiminde gelişmeler. Uludağ Üniversitesi Eğitim Fakültesi Dergisi, 19(2), 223238.

Altun, M. (2010). Illköğretim 2. kademede (6.7.8. sınıflarda) 
matematik öğretimi. (7. Baskı). Ankara: Alfa Aktüel Yayınevi.

Bahadır, E. \& Özdemir, A.Ş. (2012). İlköğretim 7. sınıf öğrencilerinin matematik kavramına ilişkin sahip oldukları zihinsel imgeler. Uluslararası Alan Araştırmaları Dergisi, 1(1), 26-40.

Balcı, A. (1999). Metaphorical ımages of school: School perceptions of students, teachers, and parents from four selected schools (In Ankara). (Yayımlanmamış Doktora Tezi). Orta Doğu Teknik Üniversitesi, Ankara.

Başar, M., Ünal, M. \& Yalçın, M. (2002). İlköğretim kademesiyle başlayan matematik korkusunun nedenleri. V.Ulusal Fen Bilimleri ve Matematik Eğitimi Kongresi, 212-216.

Burns, C. P., Roe B.D. \& Ross E.P. (1992). Teaching reading in today's elementary schools. Boston: Houghton Mifflin Company.

Carter, G. \& Norwood K. S. (1997).The relationship between teacher and student beliefs about mathematics. School Science and Mathematics, 97(2), 62-67.

Chu, E. H. \& Williams, J. D, (1996), Effects of parental involvement on eight-grade achievement. The School Counselor, 69, 126-142.

Dam, H. (2008). Öğrencinin okul başarısında aile faktörü. Hitit Üniversitesi Ilahiyat Fakültesi Dergisi, 7(14), 75 99.

Ersoy, E. \& Aydın, E. (2017). İlköğretim öğrencilerinin matematiğin günlük yaşamla olan ilişkisine yönelik metaforik algıları. Sakarya Üniversitesi Ĕgitim Fakültesi Dergisi, 33, 1-17.

Funkhouser, J. E. \& Gonzales, M. R. (1997). Family involvement in children's education: Successful local approaches: An idea book. Washington, DC: U. S. Department of Education, Office of Educational Research and Improvement.

Griffith, J. (1996). Relation of parental involvement, empowerment and school traits to student academic performance. Journal of Educational Research, 90(1), 33-41.

Güler, G., Akgün, L, Öçal, M.F. \& Doruk, M. (2012). Matematik öğretmeni adaylarının matematik kavramına ilişkin sahip oldukları metaforlar. Ĕgitim ve Öğretim Araştırmaları Dergisi, 1(2), 26-29.

Güner, N. (2013). Öğretmen adaylarının matematik hakkında oluşturdukları metaforlar. NWSA-Education Sciences, 8(4), 428-440.

Gür, H., Hangül, T. \& Kara, A. (2014). Ortaokul ve lise öğrencilerinin "matematik" kavramına ilişkin sahip oldukları metaforların karşılaştııılması. International Journal of Social Science, 25(I), 427-444.

Güveli, E., İpek, S., Atasoy, E. \& Güveli, H. (2011). Sınıf öğretmeni adaylarının matematik kavramına yönelik metafor algıları. Turkish Journal of Computer and Mathematics Education, 2(2), 140-159.

Işık, A., Çiltaş, A. \& Bekdemir, M. (2008). Matematik eğitiminin gerekliliği ve önemi. KKEFD, 17, 174-184.
Lakoff, G. \& Johnson, M. (2005). Metaforlar: Hayat, anlam ve dil (Çeviren G.Y. Demir). İstanbul: Paradigma.

Miles, M.B., \& Huberman, A.M. (1994). Qualitative data analysis. Thousand Oaks, CA: Sage.

Nasibov, F. \& Kaçar, A. (2005). Matematik ve matematik eğitimi hakkında. Kastamonu Eğitim Dergisi, 13(2), 339-346.

Neslitürk, S., Çamlıbel Çakmak, Ö. \& Asar, H. (2014). Okul öncesi öğretmenlerinin "veli" kavramına ilişkin metaforik algıları. Adıyaman Üniversitesi Sosyal Bilimler Enstitüsü Dergisi, 7(18), 679-712.

Noyes, A. (2006). Using metaphor in mathematics teacher preparation. Teaching and Teacher Education, 22, 898-909.

Oflaz, G. (2011). Illköğretim öğrencilerinin 'matematik' ve 'matematik öğretmeni' kavramlarına ilişkin metaforik algıları. 2. International Conference on New Trends in Education and Their Implications, 884-893.

Palmquist, R. A. (2001). Cognitive style and users' metaphors for the web: An exploratory study. The Journal of Academic Librarianship, 27(1), 24-32.

Perry, C. \& Cooper, M. (2001). Metaphors are good mirrors: reflecting on change for teacher educators. Reflective Practice, 2(1), 41-52.

Prank M. L. (1990). "What myths about mathematics are he1d and conveyed by teachers?" Arithmetic Teacher, 37(5), 10-12.

Reeder, S., Utley, J., \& Cassel, D., (2009). Using metaphors as a tool for examining preservice elementary teachers' beliefs about mathematics teaching and learning. School Science and Mathematics, 109(5), 290-297.

Ryan, J. (1998). Teacher development and use of portfolio assessment strategies and impact on instruction in mathematics. (Doctoral Thesis). Standford University.

Saban, A. (2004). Giriş düzeyindeki sınıf öğretmeni adaylarının "öğretmen" kavramına ilişkin ileri sürdükleri metaforlar. Türk Eğitim Bilimleri Dergisi, 2(2). 131155.

Semerci, Ç. (2007). Program geliştirme kavramına ilişkin metaforlarla yeni ilköğretim programlarına farklı bir bakış. Cumhuriyet Üniversitesi Sosyal Bilimler Dergisi, 31(2), 125-140.

Sterenberg, G. (2008). Investigating teachers' images of mathematics. Journal of Mathematics Teacher Education, 11, 89-105.

Şahin, B. (2013). Öğretmen adaylarının "matematik öğretmeni", "matematik" ve "matematik dersi" kavramlarına ilişkin sahip oldukları metaforik algılar. Mersin Üniversitesi Ĕgitim Fakültesi Dergisi, 9(1), 313321.

Tarim, K., Bulut Özsezer, M.S. \& Canbazoğlu, H.B. (2017). Sınıf öğretmeni adaylarının matematik ve matematik öğretimine ilişkin algıları. Ahi Evran Üniversitesi Kırşehir Eğitim Fakültesi Dergisi, KEFAD, 18(3), 10321052. 
Taylor, W. (1984). Metaphors of education, Heineman Educational Books Ltd, London.

Umay, A. (2003). Matematiksel muhakeme yeteneği. Hacettepe Üniversitesi Eğitim Fakültesi Dergisi, 24 234-243.

Underhill, R.G. (1988). Focus on research into practice in diagnostic and prescriptive mathematics. Focus on Learning Problems in Mathematics. 10(3): 43-58.

Yıldırım, A. \& Şimşek, H. (2011). Sosyal bilimlerde nitel araştırma yöntemleri. Ankara: Seçkin Yayıncılık.

Yob, I. M. (2003).Thinking constructively with metaphors. Studies in Philosophy and Education, 22, 127-138. 